\author{
Jerzy Bukowski
}

\title{
Przestrzeń międzyludzka w powieściach Fiodora Dostojewskiego
}

\section{Streszczenie}

Twórczość Fiodora Dostojewskiego ma duże znaczenie dla kształtowania się XX-wiecznej filozofii dialogu. Jego spojrzenie na bohatera powieściowego jest zawsze rezultatem skonfrontowania własnej świadomości ze świadomością innych, czemu sprzyja przejście od narracji auktorialnej do personalnej: postaci, opisując swoje przeżycia i sposób postrzegania świata, prowadzą dialogi wewnętrzne, które pomagają im odnaleźć lub nadać sens własnej egzystencji.

Prawda o mnie lub o innym człowieku odsłania się w spotkaniach z innymi ludźmi, ale nie może być precyzyjnie opisana, ponieważ zagubiłaby się wtedy spontaniczność, autentyczność i wielowymiarowość osoby. Aby mogło dojść do otwarcia drugiemu kredytu zaufania, człowiek mu się przed nim otworzyć, nawet jeżeli zamiast wzajemności napotyka mur obojętności lub nienawiści.

Takie właśnie, przepełnione szczerością, a zarazem żądzą wypowiedzenia „,nowego słowa" (może to być myśl, idea, wynalazek, zmiana społeczna, dokonanie rewolucyjnych zmian), spotkania bohaterów Zbrodni i kary, Idioty i Braci Karamazow analizowane są w artykule. Dostojewski prezentuje w nich istotę tego, co może zdarzyć się między ludźmi, kiedy pozwalają porwać się niezwykłym przeżyciom o wielkiej mocy, zrzucając chętnie zakładane na co dzień maski.

Słowa kluczowe: spotkanie, ,nowe słowo”, dialog, autentyzm.

Jerzy Bukowski, Uniwersytet Ekonomiczny w Krakowie, Katedra Filozofii, 31-510 Kraków, ul. Rakowicka 27, e-mail: bukojer@o2.pl 
Są myśliciele, którzy tworzą swoje dzieła w pięknej literacko formie (św. Augustyn, Henryk Bergson, Jean Paul Sartre, Albert Camus), ale nie brak również pisarzy potrafiących zgłębić poważne problemy metafizyczne, aksjologiczne, etyczne, a także psychologiczne. Do czołowych przedstawicieli tej drugiej grupy należą Fiodor Dostojewski i Franz Kafka. Obu uważa się za prekursorów egzystencjalizmu, chociaż autor Zbrodni i kary odżegnywał się od naukowych kontekstów swoich powieści, deklarując: „W ramach pełnego realizmu znaleźć w człowieku człowieka... Nazywają mnie psychologiem, to nieprawda, jestem tylko realistą w sensie wyższym, czyli przedstawiam wszystkie głębiny duszy ludzkiej” [Bachtin 1970, s. 92].

Dostojewski nie tylko kategorycznie zaprzeczał temu, że uprawia psychologię (co usiłowano mu wmawiać już za życia), ale często drwił z niej, jak również z wszelkich prób zamknięcia w sztywne ramy pojęciowe tego, co dzieje się we wnętrzu człowieka, w czym przypominał personalistów.

Trafnie ujął to w syntetycznym skrócie Michaił Bachtin: „Bohater interesuje Dostojewskiego jako odrębny punkt widzenia, jako spojrzenie na świat i samego siebie" [Bachtin 1970, s. 71].

To spojrzenie jest jednak rezultatem skonfrontowania własnej świadomości ze świadomością innych. Patrząc z filologicznego punktu widzenia, można tu dojrzeć zastąpienie narracji auktorialnej personalną, analizując zachowanie postaci z jego powieści w kategoriach filozoficznych, można zaś powiedzieć, że usuwając wszechwiedzącego narratora na poziom zajmowany przez bohaterów, spowodował ich równouprawnienie. Opisując swoje przeżycia i świat, często prowadzą oni dialogi wewnętrzne, starając się spojrzeć na siebie, na innych i na cały świat dialogicznie.

Właśnie dialogiczność, która jest niezbędnym (aczkolwiek nie wystarczającym) warunkiem spotkania osób, stanowi wyróżnik powieści Dostojewskiego. I nie chodzi wyłącznie o sferę słowną, dialogiczne mogą być bowiem sytuacje, gesty, spojrzenia; nawet myślenie bohaterów ma taki charakter, ponieważ włączają oni w jego obręb wszystko, co zapadło im w pamięć z rozmów oraz z wydarzeń z bliższej i dalszej przeszłości. Znakomitym przykładem jest wewnętrzny monolog Rodiona Raskolnikowa [Dostojewski 1966, s. 51-56].

Autor Zbrodni i kary traktuje dialogiczność w sposób, który przypomina Sokratejską dociekliwość w stosowanej przez ateńskiego myśliciela metodzie elenktycznej, jak i w metodzie maieutycznej. Chęć dotarcia do istoty problemów, przed którymi nieoczekiwanie stają bohaterowie powieści Dostojewskiego, często zmuszając ich do przewartościowania dotychczasowego sposobu myślenia, przywodzi na myśl sposób bycia nieustępliwego w dążeniu do prawdy Sokratesa, który również lubił konfrontować się (niekiedy bardzo ostro) z rozmówcami, aby znaleźć rozwiązanie nurtującego go zagadnienia. Czyż wielki starożytny moralista nie 
prowadził większości swoich rozmów tak naprawdę sam ze sobą, będąc prekursorem wszelkiej dialektyki i filozofii spotkania?

Ta dialogiczność nie kłóci się jednak z poczuciem niezależności i samodzielności bohaterów autora Braci Karamazow. Najbardziej oburzają ich właśnie próby nadania ich postępowaniu jednoznacznego sensu przez innych. Traktują takie zachowania jako zamach na swoją wolność i zaburzenie spontaniczności kontaktów międzyludzkich, nawet jeżeli jest to cena dojścia do prawdy. Za takie podejście do Hipolita ostro krytykuje Agłaja księcia Myszkina w Idiocie: „Pan nie ma w sobie krzty delikatności, pana obchodzi tylko prawda, takie stanowisko jest niesprawiedliwe" [Dostojewski 1971, s. 473].

Prawda o mnie lub o innym człowieku może mi się odsłonić w spotkaniu, ale nigdy nie jest adekwatnie opisana, ponieważ gubiłaby się wtedy spontaniczność, autentyczność i wielowymiarowość osoby. Zdaniem Dostojewskiego to, co jest w człowieku najbardziej intrygujące, fascynujące i zarazem twórczo niepokojące, skłaniające do dalszych poszukiwań umyka jednoznacznym definicjom.

Celem mojego postępowania wobec drugiego człowieka nie może być dążność do zrozumienia go w taki sposób, w jaki pojmuje się twierdzenia matematyki czy fizyki po przeprowadzeniu dowodu według ścisłych reguł. To, co ważne, dzieje się w przestrzeni międzyludzkiej, żeby przywołać pojęcie chętnie używane przez Martina Bubera i Józefa Tischnera.

Najważniejsi bohaterowie Dostojewskiego starają się zachować delikatność w relacjach z innymi ludźmi, chociaż bywają one często gwałtowne w formie i towarzyszy im niezwykłe napięcie emocjonalne. Bez wewnętrznej gotowości do spotkania z drugim człowiekiem nigdy ono nie nastąpi, co celnie podsumował Bachtin: „Tylko przy wewnętrznym nastawieniu dialogowym moje słowo nawiązuje ścisły kontakt ze słowem cudzym, jednakże nie stapia się z nim, nie wchłania go w siebie, nie przytłacza jego wagi wagą własną - czyli w pełni honoruje jego samodzielność jako słowa" [Bachtin 1970, s. 97].

Jeżeli chcę, aby wydarzyło się spotkanie, muszę wyzbyć się wszelkiej interesowności, wszelkiego zakłamania, wietrzenia jakiegokolwiek interesu. Muszę być prostolinijny i naiwny aż do granic śmieszności, zupełnie jak książę Lew Myszkin. Nie bez przyczyny powieść o nim nosi tytuł Idiota, ponieważ taka postawa może się wydawać nienaturalna i kojarzyć z chwilową lub trwałą utratą zdolności korzystania z przymiotów intelektu.

Dostojewski na długo przed Buberem, Marcelem czy Tischnerem wiedział, że jeżeli zdołam przekonać drugiego człowieka do odkrycia tego, co Max Scheler nazywał „sferą intymną", ale nie odwzajemnię mu się identyczną postawą, nie tylko nie dojdzie do spotkania, ale będziemy mieli do czynienia z nadużyciem zaufania i moralnym wyzyskiem, zwłaszcza jeśli niecnie i perfidnie udaję, że się przed nim odsłaniam. 
Nie ma też mowy o spotkaniu, kiedy otwieram się przed innym, chcąc dobrowolnie i ze szczerym sercem odsłonić swoje tajemnice, ale traktuję go jedynie jako słuchacza, powiernika, spowiednika. Do takich przypadków należą pijacki monolog Marmieładowa wygłoszony przed Raskolnikowem, spowiedź Stawrogina przed Tichonem i „moje niezbędne wyjaśnienie” Hipolita odczytane przed liczną i - jak się finalnie okazało - skrajnie nieżyczliwą publicznością.

Masochistyczne i ekshibicjonistyczne wywnętrzenie się jest charakterystyczne dla rosyjskiej mentalności (szerokiej, słowiańskiej duszy). Nie wyczerpuje się ono jednak w jawnym wyznaniu win - kończy się gotowością do poniesienia przepisanej prawem lub zwyczajem kary, za którą to cenę raz na zawsze wyzwala z wewnętrznego cierpienia. Nawet zsyłka na Syberię nie wydaje się wtedy niczym strasznym, skoro oczyściłem się z grzechu (winy), a więc z radością i z nadzieją oczekuję należnego mi wyroku tak w porządku prawnym (ludzkim), jak i boskim (eschatologicznym).

Najbardziej charakterystycznym przykładem jest w tej materii ,powszechna spowiedź” Raskolnikowa, jego ukorzenie się przed rosyjskim ludem, a zarazem przed każdym człowiekiem z osobna na chwilę przed formalnym przyznaniem się do podwójnego morderstwa sędziemu Porfiremu. To ukorzenie jest już - przed procesem, wyrokiem i zesłaniem - początkiem prawdziwej pokuty w obliczu Boga i ludzi. Nie ma bowiem gorszego stanu duszy niż samotne przeżywanie własnych grzechów.

Właśnie dlatego bohaterowie Dostojewskiego tak lgną do bratnich serc, chociaż często zamiast wzajemności napotykają mur obojętności lub nienawiści. Sonia kocha Raskolnikowa i jest gotowa do największych poświęceń dla zbawienia jego duszy, bez wahania decyduje się więc na pójście z nim na Syberię. Książę Myszkin z dziecięcą ufnością otwiera się na wielu bliźnich, ale najczęściej spotyka się z zawodem, jak choćby w relacjach z Rogożynem. Alosza Karamazow koniecznie chce uratować przed potępieniem dusze swoich starszych braci.

Większość postaci z powieści autora Biesów ma jeszcze jeden problem: koniecznie chcą wypowiedzieć „nowe słowo” (określenie Bachtina): o sobie, o innych, o świecie. Ich próby zaistnienia w przestrzeni publicznej wiążą się więc nie tylko z pragnieniem przeżycia czegoś wzniosłego w kontaktach z bliźnimi, ale także wyraźnego zaznaczenia swojej obecności wśród nich. „Nowym słowem” może być myśl, idea, wynalazek, zmiana społeczna (dokonanie rewolucji), jakiś rodzaj apostolstwa. Jedni mówią o tym głośno, a nawet zamęczają otoczenie, inni są bardziej dyskretni (skryci), ale nie zaprzestają wysiłków.

Jako przykłady spotkań o wyjątkowym natężeniu emocjonalnym, a zarazem przynoszących poważne aksjologiczne i etyczne konsekwencje wybrałem trzy.

Pierwsze z nich to dialogi Soni z Raskolnikowem. Jest w nim wiele zapowiedzi tego, co stanie się w przyszłości. Główny bohater Zbrodni i kary obiecuje wyjawić 
swej partnerce swoją największą tajemnicę: kto i dlaczego zabił starą lichwiarkę Lizawietę oraz jej siostrę. Podczas kolejnego spotkania stara się przedstawić jej „socjologiczne" wytłumaczenie popełnionego przez siebie przestępstwa, ale czuje fałsz swych słów i ogromną potrzebę powiedzenia prawdy, która będzie „nowym słowem", czyli usprawiedliwieniem przekroczenia prawa (aż do zbrodni) przez silnego człowieka.

Wszystko, co stanie się potem, będzie już tylko efektem owych dwóch przełomowych rozmów i w naturalny sposób doprowadzi go do publicznego wyjawienia prawdy o dokonanym przezeń zabójstwie, skutkującego katorgą, podczas której Sonia będzie mu wiernie towarzyszyć. I właśnie tam, na Syberii, po raz trzeci „przewyższą siebie” w horyzoncie agatologicznym, budując trwałą wspólnotę osobową na całe dalsze życie.

Dostojewski głęboko wierzył, że odkupienie winy jest możliwe tylko poprzez triadę: publiczne wyznanie - stanowiące zadośćuczynienie cierpienie - dająca nadzieję na całkowitą przemianę wewnętrzną miłość. Surowość prawosławia nie wyklucza miłosierdzia, a rosyjska dusza gotowa jest poddać się upokarzającemu w formie oczyszczeniu (katharsis), skoro odrzuci lęk, wstyd i egoistyczne przekonanie o swej przewadze nad bliźnim, a także nad całym światem.

Kluczowy dla owej przemiany jest poniższy fragment:

Mam teraz tylko ciebie - dodał. - Będziemy szli razem... Przyszedłem do ciebie. Obojeśmy przeklęci, wspólnie też pójdziemy.

Oczy mu pałały. Niby niespełna rozumu! - z kolei pomyślała Sonia.

- Gdzie mamy iść? - spytała w strachu i bezwiednie cofnęła się.

- Czy ja wiem? Wiem tylko tyle, że jedną pójdziemy drogą, to wiem na pewno - tylko tyle. Wspólny cel.

Spojrzała na niego, nic nie rozumiejąc. Zdawała sobie sprawę tylko z tego, że okropnie, bezgranicznie jest nieszczęśliwy.

- Nikt z tamtych nie zrozumie nic, jeśli będziesz im mówiła - ciągnął dalej - ja zaś zrozumiałem. Potrzebna mi jesteś, dlatego też przyszedłem do ciebie.

- Nie rozumiem - wyszemrała.

-Zrozumiesz później. [...] Lecz ty wytrzymać nie możesz i jeżeli pozostaniesz sama, zwariujesz jak i ja. Już i teraz jesteś jak błędna, a zatem musimy iść razem, jedną drogą. Idźmy! [Dostojewski 1966, s. 55-56].

Pierwsze spotkanie księcia Lwa Nikołajewicza Myszkina z Nastazją Filipowną Baraszkow wydarza się w warunkach, które przeczą jakiejkolwiek intymności, a nawet prywatności: wśród wielu ludzi, w ogromnym zgiełku i w stanie ogólnego podniecenia wszystkich obecnych. Do kulminacji dochodzi w momencie spoliczkowania księcia przez Ganię Iwołgina. W tym momencie „prostaczek boży" o głębokim sercu, nieograniczonej ufności do ludzi, przepełniony miłością do świata staje twarzą w twarz z „kobietą fatalną” kreującą się na wyuzdaną 
i cyniczną kurtyzanę, jawnie drwiącą z otoczenia, prowokującą dramatyczne sytuacje, ustawiającą całe towarzystwo według zachcianek i kaprysów swej niepohamowanej woli, budzącą powszechną zazdrość oraz nienawiść. Można powiedzieć: oto spotkanie dobra i zła.

- A pani wcale nie wstyd! Czy pani jest taka, za jaką chciała pani uchodzić? Czy to w ogóle możliwe! - zawołał nagle książę z głębokim, serdecznym wyrzutem.

Nastazja Filipowna zdziwiła się, uśmiechnęła, ale jakby coś ukrywając pod swoim uśmiechem, z pewnym zmieszaniem spojrzała na Ganię i wyszła z bawialni. Nie doszedłszy jeszcze do przedpokoju, nagle zawróciła, szybko podeszła do Niny Aleksandrowny, wzięła jej rękę i podniosła do ust.

- Rzeczywiście, nie jestem taka, zgadł - szepnęła z pośpiechem, żarliwie, zarumieniła się nagle, zapłoniła i odwróciwszy się, wyszła tym razem tak prędko, że nikt się nie zdążył zorientować, w jakim celu wracała [Dostojewski 1971, s. 132].

Następne kontakty Myszkina z Nastazją również odbywają się w atmosferze niebywałego harmideru, co potwierdza tezę, że spotkanie może się wydarzyć w dowolnych okolicznościach. Od opisanej wyżej sceny Nastazja nie potrafi już skryć się za żadną maską ani skutecznie teatralizować swojego życia, chociaż usiłuje - niejako w samoobronie przed odsłonięciem się - traktować księcia wyjątkowo brutalnie, obcesowo, szyderczo. Usiłuje wtłoczyć go w aranżowane przez siebie sytuacje, ale dochodzi do kolejnego przełomu:

Uklękła przed nim na ulicy jak obłąkana: cofnął się w strachu, a ona chwytała jego rękę, żeby ją całować i zupełnie tak samo jak wtedy we śnie, na jej długich rzęsach błyszczały łzy.

- Wstań, wstań! - mówił przerażonym szeptem, podnosząc ją. - Wstań prędzej!

- Jesteś szczęśliwy? Szczęśliwy? - pytała. - Powiedz mi jedno tylko słowo, czy jesteś teraz szczęśliwy? Dzisiaj, w tej chwili? U niej? Co powiedziała?

Nie podnosiła się z klęczek, nie słuchała go: pytała z pospiechem i mówiła prędko, jakby ją ścigała pogoń.

- Jadę jutro, tak jak kazałeś. Nie będę... Ostatni przecież raz cię widzę, ostatni! Teraz to już naprawdę ostatni raz!

- Uspokój się, wstań! - powiedział z rozpaczą.

Chciwie wpatrywała się w niego, uczepiwszy się jego rąk.

- Żegnaj! - rzekła wreszcie, wstała i szybko odeszła, prawie pobiegła [Dostojewski 1971, s. 507].

Wreszcie nadszedł czas na ich naprawdę ostatnie spotkanie, najbardziej intymne w formie:

Książę siedział obok Nastazji Filipowny, nie spuszczał z niej oka i gładził ją po główce i po twarzy oburącz, jak małe dziecko. Śmiał się, kiedy ona się śmiała i gotów był płakać na widok jej łez. Nic nie mówił, ale uważnie wsłuchiwał się 
w jej urywany, chaotyczny bełkot, wątpliwe, czy coś rozumiał z tego, uśmiechał się jednak w milczeniu i gdy tylko wydało mu się, że ona znów rozpacza albo szlocha, czyni mu wyrzuty albo się skarży, natychmiast znów ją zaczynał głaskać po główce i delikatnie wodzić rękami po jej policzkach, pocieszając ją i perswadując jak dziecku [Dostojewski 1971, s. 631].

Po tylu gwałtownych przeżyciach, napięciach, namiętnościach następuje tragiczny i mroczny finał, czyli zabójstwo Nastazji przez Rogożyna, a po nim jeszcze jego wstrząsający dialog z księciem Myszkinem.

Ostatni przykład to spotkanie Aloszy i Iwana Karamazowych:

- Któż zatem jest zabójcą według ciebie? - zapytał ozięble i nawet jakoś wyniośle.

- Sam wiesz kto - cicho i przejmująco odrzekł Alosza.

- Kto? Ta bajka o obłąkanym idiocie, epileptyku? O Smierdiakowie?

Alosza poczuł nagle, że drży jak w gorączce.

- Ty sam wiesz kto - wyrzekł bezsilnie.

Brakło mu tchu.

- Ale kto, kto? - z wściekłością prawie zawołał Iwan.

Stracił całą swą powściągliwość.

- Wiem tylko jedno - mówił szeptem Alosza - nie ty zabiłeś ojca.

- Nie ty! Co to znaczy: nie ty? - zdumiał się Iwan.

- Nie ty zabiłeś ojca, nie ty! - powtórzył z mocą Alosza.

Chwilę trwało milczenie.

- Ależ sam wiem, że nie ja, co ty bredzisz? - uśmiechnął się Iwan blado i z grymasem.

Jakby pożerał wzrokiem Aloszę. Obaj znowu stali koło latarni.

- Nie, Iwanie, sam sobie kilka razy mówiłeś, że jesteś zabójcą.

- Kiedy mówiłem? Byłem w Moskwie... Kiedy mówiłem? - bąknął Iwan do reszty zmieszany.

- Mówiłeś to sobie wiele razy, gdy byłeś sam przez te okropne dwa miesiące wciąż cicho i wyraźnie mówił Alosza.

Ale teraz mówił jakby nie od siebie, nie z własnej woli, lecz jakby ulegając jakiemuś nieodpartemu rozkazowi.

- Oskarżałeś siebie i przyznawałeś się, że zabójcą jesteś tylko ty. Ale nie ty zabiłeś, mylisz się, nie jesteś zabójcą, czy słyszysz mnie, nie ty. Bóg mnie posłał, aby ci to powiedzieć.

Obaj milczeli. Długą chwilę trwało to milczenie. Obaj byli bladzi. [...]

- Bracie - zaczął drżącym głosem Alosza - powiedziałem ci to dlatego, że mi uwierzysz, wiem to. Na całe życie powiedziałem ci to słowo: nie ty! Słyszysz, na całe życie. I Bóg kazał mi to powiedzieć, choćbyś mnie miał od tej chwili na zawsze znienawidzieć [Dostojewski 1959, t. II, s. 312-313].

Całkowite otwarcie się i pragnienie wypowiedzenia najbardziej skrywanych, intymnych przeczuć, ukazania bratu całej prawdy o sobie, wyjawienia dręczącej 
go tajemnicy, której on sam nie ogarnia, cechują postawę Iwana wobec Aloszy, chociaż pozornie zachowuje się (podobnie jak Nastazja Filipowna wobec księcia Myszkina) w stosunku do niego oschle i jak gdyby oficjalnie.

- Od tej chwili zrywam z panem, i zdaje się, na zawsze. Pańska droga prowadzi zresztą nie tędy. Szczególnie niech się Pan nie waży przyjść do mnie dzisiaj! Słyszy pan?

Obrócił się i stanowczym krokiem poszedł przed siebie.

- Bracie! - krzyknął za nim Alosza - jeżeli się dzisiaj coś z tobą stanie, to pomyśl przede wszystkim o mnie.

Ale Iwan nie odpowiedział [Dostojewski 1959, t. II, s. 313].

Dostojewski nie oszczędza swoich bohaterów. Można powiedzieć, że lubuje się w dokonywaniu wiwisekcji ich dusz, ale tak daleko posunięta otwartość charakteryzuje ludzi, dla których nie liczą się żadne konwenanse ani obyczajowe bariery. W podobny sposób łamali je religijni prorocy, narażając się na gniew otoczenia, ale zyskując powszechne poważanie tych, do których trafiały ich przesłania.

Przytoczone wyżej spotkania wykreowanych przez Dostojewskiego postaci literackich prezentują istotę tego, co może zdarzyć się między ludźmi, kiedy pozwalają porwać się niezwykłym przeżyciom o wielkiej mocy. W zgiełku codziennej krzątaniny jesteśmy zupełnie inni i trudno nam uwierzyć, że możemy kiedykolwiek zrzucić chętnie zakładane maski i zasłony.

Z punktu widzenia powszedniości w spotkaniu dzieją się dziwne rzeczy, dominuje nienaturalne napięcie emocjonalne i wolicjonalne. Często, przeżywając coś niezwykłego, zadajemy sobie pytanie, czy nie popadamy w jakiś chorobliwy stan, którego lepiej byłoby uniknąć, ratując w ten sposób fizyczne i psychiczne zdrowie. A jeżeli nie da się go powstrzymać, bo opanowuje nas gwałtownie i znienacka, to może trzeba je zbagatelizować i potraktować w kategoriach nic nieznaczącego ewenementu, nie zaś przełomowego wydarzenia w naszym życiu.

Dostojewski uczy nas nie gorzej niż Martin Heidegger, Jean Paul Sartre, Albert Camus czy Gabriel Marcel, że człowiek dusi się w codzienności i czuje nieautentyczność swojej egzystencji, dopóki nie nastąpi coś, co pozwoli mu przewartościować życie, zdobyć się na odwagę odrzucenia spraw mających znaczenie w porządku społecznym, ale bezwartościowych w osobowym. Dostrzegają to na równi fenomenologowie (odejście od doświadczeń źródłowych), egzystencjaliści (popadnięcie w technokrację i alienację), filozofowie chrześcijańscy (zapomnienie o istocie i powołaniu człowieka), personaliści (zdegradowanie osoby do roli przedmiotu), a nawet psychoanalitycy (uwikłanie w kompleksy cywilizacyjne).

Podobnie jak bohaterowie autora Biesów często zdajemy sobie sprawę z tego, że życie przecieka nam przez palce, a szarość i chaos codziennego trudu rozpraszamy automatyzmem rozrywki (ten ból znał już Błażej Pascal), mechanicznie realizowanymi zadaniami bieżącymi, marzeniami, tłumiąc brak siły woli, co 
przypomina słynne zawołanie Mrożkowego Kapitana: „Jezu słodki, żeby mi się chciało! Żeby mi się tylko chciało!" [Mrożek 1975, s. 61].

Postaci z powieści Dostojewskiego chcą się wyrwać z tej nieautentyczności i anonimowości, które Heidegger określa trudno przetłumaczalnymi na język polski słowami man lebt, oznaczającymi, że jako „rzucony w świat” bezwolny byt płynę niesiony falami niczym kawałek drewna (obrazowo i sugestywnie opisał to Sartre w Drogach wolności).

Rodion Raskolnikow, Sonia Marmieładowa, książę Lew Nikołajewicz Myszkin, Nastazja Filipowna, Agłaja Jepanczyn, Rogożyn, wszyscy trzej bracia Karamazow wyrywają się z tej gnuśności, chociaż wiedzą (aczkolwiek może nie od początku), jaką cenę będą zmuszeni zapłacić za stanie się w pełni osobą ludzką. Cierpienie z powodu uświadomienia sobie własnej niemocy duchowej i moralnego upadku zostaje zastąpione męką autentyczności spowodowanej pełnym otwarciem się na drugiego człowieka i zaryzykowaniem możliwości bycia przez niego perfidnie wykorzystanym. Ale bywa tak, że trzeba zaryzykować i rozsadzić mury obojętności, aby zacząć wreszcie naprawdę żyć. Tak ujął to Camus:

Czasem rozsypuje się dekoracja. Poranne wstawanie, tramwaj, cztery godziny w biurze albo w fabryce, posiłek, tramwaj, cztery godziny pracy, sen i poniedziałek wtorek środa czwartek piątek i sobota w tym samym rytmie: najczęściej tą drogą idzie się łatwo. Tylko, że pewnego dnia pojawia się „dlaczego" i wszystko rozpoczyna się w znużeniu zabarwionym zdumieniem. Rozpoczyna się to ważne. Znużenie jest u końca czynów machinalnego życia, ale inauguruje zarazem ruch świadomości. Budzi ją i prowokuje ciąg dalszy. Jest nim niedoświadczony powrót do łańcucha albo przebudzenie definitywne. U jego końca pojawia się z czasem konsekwencja: samobójstwo lub nawrót do poprzedniego stanu. [...] W codzienności szarego życia unosi nas czas. Ale przychodzi zawsze chwila, kiedy my mamy go unieść. Żyjemy przyszłością: jutro, później, kiedyś się urządzisz, z wiekiem zrozumiesz. Godne podziwu niekonsekwencje [Camus 1971, s. 100].

Autor Zbrodni i kary nie używał wprawdzie pojęcia życia autentycznego, które pojawia się dopiero w filozofii XX w. (głównie u egzystencjalistów), ale jest ono wyraźnie obecne w jego twórczości. Powyższy cytat z Esejów Camusa doskonale pasuje przecież do charakterystyki postaci z powieści Dostojewskiego. Ich usiłowanie wyrwania się z marazmu codziennego życia oraz wypowiedzenia „,nowego słowa" jest równie często krzykiem rozpaczy, co przejawem buntu i wyrażaniem tęsknoty za autentycznością, choćby miała ona wiele kosztować. Niekiedy odnosi się wrażenie, iż z masochistycznym upodobaniem dążą oni do tego, aby ta cena była maksymalnie wysoka i żeby sami sobie nie mogli postawić zarzutu jakiegokolwiek zaniedbania.

Bohaterowie Dostojewskiego nie chcą podtrzymywać dekoracji ani kryć się $\mathrm{w}$ ich zakamarkach z poczuciem bezpieczeństwa, ale zarazem rezygnacji 
z dążenia do wysokich wartości. Nie potrafią - jak w opowieści o Wielkim Inkwizytorze z Braci Karamazow - oddać wolności za chleb. Przeraża ich perspektywa marnej egzystencji aż do śmierci w błogim przywiązaniu do budowanego od lat złudzenia, że man lebt to prawdziwe życie. Są gotowi do zdjęcia masek bez względu na możliwe konsekwencje takiej decyzji. I ponoszą je z godnością.

\section{Literatura}

Bachtin M. [1970], Problemy poetyki Dostojewskiego, przekł. N. Modzelewska, Państwowy Instytut Wydawniczy, Warszawa.

Camus A. [1971], Eseje, przekł. J. Guze, Państwowy Instytut Wydawniczy, Warszawa.

Dostojewski F. [1959], Bracia Karamazow, przekł. A. Wat, Państwowy Instytut Wydawniczy, Warszawa.

Dostojewski F. [1966], Zbrodnia i kara, przekł. C. Jastrzębiec-Kozłowski, Państwowy Instytut Wydawniczy, Warszawa.

Dostojewski F. [1971], Idiota, przekł. J. Jędrzejewicz, Państwowy Instytut Wydawniczy, Warszawa.

Mrożek S. [1975], Indyk [w:] Wybór dramatów i opowiadań, Wydawnictwo Literackie, Kraków.

\section{Interpersonal Space in Fyodor Dostoyevsky's Novels}

(Abstract)

The works of Fyodor Dostoyevsky played an important role in shaping the 20th century philosophy of dialogue. His view on the novel's protagonist is always the result of confronting his own consciousness with the consciousness of others, which is facilitated by shifting from auctorial to personal narration: the characters, describing their experiences and outlook, conduct an internal dialogue which helps them to find or make sense of their own existence.

The truth about me or about another person is revealed in encounters with other people but it cannot be described with precision because the spontaneity, authenticity, and multidimensionality of the person would otherwise be lost. In order to give another person the credit of trust, we must open to them even if, instead of reciprocity, we encounter indifference or hatred.

This article analyses such encounters of the protagonists of Crime and Punishment, The Idiot, and The Brothers Karamazov; encounters which are replete with honesty as well as the desire to utter "a new word" (this could be a thought, an idea, an invention, a social change, a revolutionary change). In them, Dostoyevsky presents the essence of what can happen between people when they let themselves be overwhelmed by exceptional and powerful experiences and take off the masks and veils readily used every day.

Keywords: encounter, "new word", dialogue, authenticity. 